\title{
CAPITAL ACCOUNT LIBERALIZATION: ALLOCATIVE EFFICIENCY OR ANIMAL SPIRITS?
}

\author{
Anusha Chari \\ Peter Blair Henry \\ Working Paper 8908 \\ http://www.nber.org/papers/w8908 \\ NATIONAL BUREAU OF ECONOMIC RESEARCH \\ 1050 Massachusetts Avenue \\ Cambridge, MA 02138 \\ April 2002
}

Henry gratefully acknowledges the financial support of an NSF CAREER award and the Stanford Institute of Economic Policy Research (SIEPR). We thank Steve Buser, Paul Romer, Antoinette Schoar and René Stulz for helpful comments. We also thank seminar participants at the AEA, Michigan and Stanford. All remaining errors are our own. The views expressed herein are those of the authors and not necessarily those of the National Bureau of Economic Research.

(C) 2002 by Anusha Chari and Peter Blair Henry. All rights reserved. Short sections of text, not to exceed two paragraphs, may be quoted without explicit permission provided that full credit, including $\odot$ notice, is given to the source. 
Capital Account Liberalization: Allocative Efficiency or Animal Spirits?

Anusha Chari and Peter Blair Henry

NBER Working Paper No. 8908

April 2002

JEL No. E2, F3, F4, G31

\begin{abstract}
In the year that capital-poor countries open their stock markets to foreign investors, the growth rate of their typical firm's capital stock exceeds its pre-liberalization mean by 4.1 percentage points. In each of the next three years the average growth rate of the capital stock for the 369 firms in the sample exceeds its pre-liberalization mean by 6.1 percentage points. However, there is no evidence that differences in the liberalization-induced changes in the cost of capital or investment opportunities drive the cross-sectional variation in the post-liberalization investment increases.
\end{abstract}

Anusha Chari

University of Michigan Business School

701 Tappan Street

Ann Arbor, MI 48109-1234

achari@umich.edu
Peter Blair Henry

Stanford University

Graduate School of Business

Stanford, CA 94305-5015

and NBER

pbhenry@stanford.edu 


\section{Introduction}

There are two broad views of capital account liberalization. The first view "Allocative Efficiency" — argues that removing restrictions on international capital movements permits financial resources to flow from capital-abundant countries, where expected returns are low, to capital-scarce countries, where expected returns are high. The flow of resources into the capital-scarce countries reduces their cost of capital, increases investment, and raises output (Fischer, 1998; Stulz, 1999). The second view “Animal Spirits" — regards Allocative Efficiency as fanciful. Animal Spirits proponents argue that liberalization does not result in a more efficient allocation of capital, because international capital flows have little or no connection to real economic activity. Specifically, capital account liberalization has no effect on investment, output, or any other real variable with nontrivial welfare implications (Bhagwhati, 1998; Rodrik, 1998; Stiglitz 2000a, b, c).

This paper confronts the two opposing views of capital account liberalization with facts. In the late 1980s and early 1990s a number of capital-poor countries permitted foreigners to purchase shares in their domestic stock markets. Opening the stock market to foreign investors constitutes a discrete change in the degree of capital account openness. This allows us to examine empirically whether the behavior of prices and quantities of capital during liberalization episodes are more consistent with Allocative Efficiency or Animal Spirits.

Allocative Efficiency makes two testable predictions about the time series behavior of prices and quantities of capital during stock market liberalization episodes. First, the flow of resources into a liberalizing country reduces its cost of capital and 
drives up Tobin's $q$ - the asset market value of installed capital goods relative to their replacement cost. The second implication follows from the first. Profit-maximizing firms will respond to the increase in $q$ by installing more capital. Once the asset market value of capital goods and their replacement cost are equalized once again, investment will slow to a rate that is sufficient to maintain this equality. In other words, if the Allocative Efficiency view is correct, we should observe a temporary increase in Tobin's $q$ and investment during liberalization episodes. On the other hand, if Animal Spirits prevail, then there is no reason to expect an empirical link from liberalization to prices and quantities of capital.

Allocative Efficiency also makes predictions about the cross-sectional behavior of investment following liberalization. Opening the stock market to foreign investors alters the set of systematic risks for the representative investor, because liberalization switches the relevant benchmark for pricing individual stocks from the local market index to a world stock market index. Consequently, stock prices should move to restore equality of risk-adjusted returns when liberalizations occur. Prices should rise in sectors where systematic risk falls and fall in sectors where systematic risk rises. Under Allocative Efficiency, the reallocation of physical capital following liberalization is the dual of the stock price revaluation process. We should observe relatively more investment by firms whose systematic risk falls and relatively less by those whose systematic risk rises.

Time series and cross-sectional estimations on data from 1980 to 1994 for 369 firms in India, Jordan, Korea, Malaysia, and Thailand provide a direct test of whether Allocative Efficiency or Animal Spirits better describes the behavior of Tobin's $q$ and investment during liberalization episodes. The time series results are more consistent 
with Allocative Efficiency than with Animal Spirits; the typical firm experiences a significant increase in both Tobin's $q$ and investment around liberalization. The crosssectional results are more consistent with Animal Spirits than with Allocative Efficiency; there is no evidence that diversification motives drive the reallocation of physical investment following liberalization. Taken together, the results suggest that neither view provides a completely accurate description. Liberalizing capital markets may ensure that capital moves from low- to high-return countries, but liberalization alone may not guarantee the efficient reallocation of capital across firms within a given country.

Evidence from previous work that uses aggregate time series data supports Allocative Efficiency. Stock market liberalizations are associated with higher stock prices and increased investment in the entire economy (Bekaert and Harvey, 2000; Henry 2000a, b). In contrast, evidence from aggregate cross-sectional data supports Animal Spirits - there is no significant relationship between countries' investment-to-GDP ratios and the International Monetary Fund's (IMF) measure of their capital account openness (Rodrik, 1998).

Both sets of previous evidence are difficult to interpret. Interpreting the time series evidence is difficult, because it is not clear that an economy-wide investment boom can be attributed to a policy change that affects directly only those firms that are traded on the stock market. In contrast, this paper uses investment data for only those firms that are listed on the stock market. Since stock market liberalization directly affects the shadow value of capital for listed firms, these data provide a tighter link to the theory than aggregate investment data. 
The cross-sectional evidence is also difficult to interpret, because it does not provide a direct test of Allocative Efficiency. Examining the correlation between average investment and openness tells us whether investment rates are permanently higher in countries with capital accounts that are more open. Allocative Efficiency, however, predicts that only a temporary increase in investment will occur when a capital-poor country removes restrictions on capital inflows. This paper examines whether discrete capital account liberalization episodes lead to a temporary increase in the growth rate of the capital stock, as predicted by the theory.

One drawback of the experiment is the difficulty of isolating the effects of stock market liberalization from those of contemporaneous reforms. Liberalizations often coincide with other policy changes that might affect Tobin's $q$ and investment. Another disadvantage is that the experiment is narrow. Stock market liberalizations constitute only one specific type of capital account liberalization. Ultimately, one would like a more complete understanding of whether the evidence surrounding the broader capital account liberalization process is more or less consistent with the theory. Nevertheless, focusing on a narrow experiment allows for a relatively clean test of the two opposing views.

\section{Data and Descriptive Findings}

The primary source of data is the International Finance Corporation's Corporate Finance Database. Singh et al. (1992) and Booth et al. (2001) provide complete descriptions of the International Finance Corporation (IFC, 1999) database. The data discussion here provides only those details relevant to this paper. Between 1980 and 
1994, the IFC collected annual financial statements for a maximum of the 100 largest publicly traded, non-financial firms in eleven developing countries: Argentina, Brazil, India, Jordan, Korea, Malaysia, Mexico, Pakistan, Thailand, Turkey, and Zimbabwe. The IFC's collection criteria were that quality data were available for a reasonably large sample of firms and that developing countries from each continent were represented. For several countries, the early years of the sample did not contain data of sufficiently high quality. For these countries, the sample begins after 1980. For some of the smaller countries, fewer than 100 firms are traded or meet the data availability criteria, which resulted in smaller samples.

In order for a country to be included in our sample, the IFC must provide balance sheet and income statement data before and after the year in which a country liberalized its stock market. This before-and-after criterion, in combination with the short length of the time series in some cases, reduces the number of feasible countries to the following set of five: India, Jordan, Korea, Malaysia, and Thailand. Despite its modest size there are a total of 369 firms - the sample available from the IFC database is better suited to addressing the question of whether liberalization affects firms' investment decisions than competing databases such as Worldscope and Global Vantage. This is because the median stock market liberalization date in the sample is 1988 . Worldscope and Global Vantage contain virtually no company data before 1988.

Table 1 summarizes the essential characteristics of the countries and firms in the sample. Column 1 provides the name of the country; Column 2 lists the year in which the stock market was liberalized; Column 3 gives the number of firms in each country. Column 4 lists the ratio of stock market capitalization of the firms in the IFC sample to 
the total stock market capitalization of all publicly traded firms in the country. The stock market capitalization of the 369 firms in our sample constitutes 40 percent of total stock market capitalization. This figure indicates that the firms in the IFC Database comprise a significant fraction of all publicly traded companies in these countries.

\section{A. Construction of Firm-level Capital Stocks and Tobin's $q$}

The IFC Corporate Finance Database reports the nominal value of property, plant, and equipment on an annual basis. These annual values are divided by the local consumer price index to create an index of each firm's real capital stock. For each firm in the sample, Tobin's $q$ is the ratio of the market value of that firm's securities to the replacement cost of its tangible assets. The replacement cost of tangible assets is the book value of net fixed assets (property, plant and equipment). The market value of each firm's securities is the sum of the market value of equity - its stock market capitalization - and the book value of its current and long-term liabilities. We use book values of debt because the IFC database does not contain information on market values.

In the absence of directly observable market values of debt, the standard approach converts book values of debt to market values in two steps (Blanchard, Rhee, and Summers 1993). First, the book value of short-term debt is assumed to be the same as its market value. The second step converts the book value of long-term debt to market value by capitalizing net interest payments using the yield on Moody's corporate A bond. ${ }^{1}$ This conversion method cannot be applied directly to this study, because data on corporate bond rates are not available for the relevant time period. Estimating the market

\footnotetext{
${ }^{1}$ Equation (1) on page 357 of Von Furstenberg (1977) is used for conversion assuming a ten-year maturity.
} 
value of debt would require further assumptions about unobservable corporate bond rates. Rather than adopting a cure worse than the ailment, we follow the alternative convention of using book values of debt as proxies for market values.

Another potential concern is that the construction of Tobin's $q$ measures average, not marginal $q$. While it is marginal $q$, the ratio of the increment of market valuation to the cost of the associated investment, that matters, the same factors which raise or lower marginal $q$ will raise or lower average $q$. Thus one would also expect investment to vary with the level of average $q$.

\section{B. Do Tobin's $q$ and Investment Respond to Liberalization?}

Allocative Efficiency predicts that liberalization will raise the market value of capital. Removing restrictions on capital inflows permits financial resources to move from capital-abundant countries, where expected returns are low, to capital-scarce countries, where expected returns are high. The flow of resources into the liberalizing country reduces the average cost of capital and drives up Tobin's $q$.

If this view has any empirical bite, we should observe an increase in the typical firm's level of Tobin's $q$ relative to its pre-liberalization mean when the stock market is liberalized. Table 2 verifies this prediction. The average level of Tobin's $q$ across all 369 firms before liberalization is 3.84. The average level of Tobin's $q$ in the liberalization year is 5.61 , approximately 40 percent higher than the pre-liberalization mean. Turning to individual countries, the average level of Tobin's $q$ in the year of liberalization exceeds the pre-liberalization mean in every country except Malaysia. 
The numbers in Table 2 suggest that q increases with liberalization, but they need to be interpreted with caution. The level of Tobin's $q$ may not be directly comparable across countries, because of differences in accounting practices. For example, firms in India, Malaysia, and Jordan value assets using the practice of fair-market valuation in accordance with North American Generally Accepted Accounting Principles (GAAP). In contrast, Korea and Thailand rely on strict historic-cost accounting as in Germany and Japan (Booth et al., 2001).

In light of these differences, growth rates of $q$ provide more compatible crosscountry measures. Figure 1 shows that the average deviation of the growth rate of Tobin's $q$ from its pre-liberalization mean is 18 percentage points on impact (year [0]), 11 percentage points in the first year after liberalization (year [+1]), and 8 percentage points in the second year after liberalization (year [+2]). The cumulative deviation over years $[0,+2]$ is 37 percentage points.

Under Allocative Efficiency, profit-maximizing firms should respond to the increase in Tobin's $q$ by installing more capital. Once the asset market value of capital goods and their replacement cost are equalized again, investment should slow to a rate that is sufficient to maintain this equality. To examine this implication of the theory, Figure 2 plots the average deviation of the growth rate of the real capital stock from its pre-liberalization mean for all 369 firms. Figure 2 suggests a lagged response of investment to stock market liberalization. On impact, the growth rate of the capital stock increases sharply and remains above its pre-liberalization mean for each of the three subsequent years. Taken together, Figures 1 and 2 suggest that, on average, liberalization 
drives up the relative price of capital, and firms respond to this relative price increase by installing more capital.

\section{Time Series Evidence: Are the Increases in Tobin's $q$ and Investment Robust?}

While roughly consistent with Allocative Efficiency, Figures 1 and 2 must be interpreted with caution. They simply describe the behavior of the raw data on Tobin's $q$ and investment without controlling for firm, country, and world-specific factors that may drive $q$ and investment independently of any stock market liberalization policies. This section of the paper wrestles empirically with these issues.

\section{A. Tobin's $q$}

We begin by estimating a benchmark regression for the pooled group of 369 firms. The regression examines whether, in each of the three years immediately following stock market liberalization, the growth rate of Tobin's $q$ differs significantly from its pre-liberalization growth rate:

$\Delta(\ln q)_{i j t}=\alpha+\operatorname{Lib}[0]_{j}+L i b[+1]_{j}+\operatorname{Lib}[+2]_{j}+L i b[+3]_{j}+F I R M_{i}+\varepsilon_{i j t}$

The left-hand-side variable is the growth rate of Tobin's $q$ for firm $i$ in country $j$ in year t. $L i b[0]_{j}$ is a variable that equals one in the year that country $j$ liberalizes its stock market. $\operatorname{Lib}[+1]_{j}, \quad \operatorname{Lib}[+2]_{j}$, and $\operatorname{Lib}[+3]_{j}$ take on the value 1 in the first, second and third years after liberalization, respectively. FIRM is a set of firm-specific dummy variables, which means that the intercept term, $\alpha$, measures the average change in the growth rate of Tobin's $q$ after removing firm-specific fixed effects. 
The error term in Equation (1) requires further discussion. All firms in a given country share the same liberalization date in addition to other country-specific factors. Therefore, the standard assumption that the error term for the growth rate of Tobin's $q$ is random and uncorrelated across firms may no longer obtain. Three steps are taken to address this issue. First, the variance-covariance matrix used to calculate the standard errors was adjusted to account for clustering. Second, the estimation procedure also corrects for potential heteroscedasticity across firms. Third, estimates of Equation (1) that include country-specific fixed effects are also presented.

Table 3, Panel A presents the results. The first row presents the benchmark specification, which controls for firm-fixed effects. Moving across columns shows the estimate for each year relative to liberalization. For example, the entry under column [0] in the row labeled "Firm-fixed Effects" shows that in the year the stock market is liberalized, the growth rate of Tobin's $q$ exceeds its pre-liberalization mean by 18.2 percentage points. The adjacent column, $[+1]$, shows that in the year immediately following liberalization, the growth rate of $q$ exceeds its pre-liberalization mean by 13.2 percentage points. In year [+2], this number is 8.6 percentage points. All three estimates are statistically significant at the 1 percent level.

In year [+3] the growth rate of $q$ falls significantly below its pre-liberalization mean. The negative and significant growth rate of $q$ following an initial rise is consistent with the theory. Liberalization drives up the relative price of capital, and firms respond by increasing their capital stock with a lag. Once investment starts rising, $q$ begins falling back toward pre-liberalization levels. Shortness of the time series prevents estimation of the response of $q$ to liberalization beyond year [+3]. 
Row 2 of Panel A presents estimates that control for country-specific characteristics other than liberalization that might be driving the results. The estimates are almost identical to those that use firm-fixed effects. The growth rate of $q$ exceeds the pre-liberalization mean by 18.3 percentage points in year [0], 13.3 percentage points in year [+1], and 8.7 percentage points in year [+2]. As in the firm-specific estimates, the growth rate of $q$ falls significantly below its pre-liberalization mean in year [+3].

If liberalizations coincide with high points in the world business cycle, then Tobin's $q$ might increase independently of any change in capital account policy. There are two possible approaches to this problem: indirect and direct. The indirect approach would use year-specific dummy variables to control for movements in the world business cycle. The potential for multicollinearity of the year dummies with the liberalization variable makes this indirect approach unadvisable. Therefore, we attempt to control directly for movements in the world business cycle by including the contemporaneous growth rate of OECD industrial production, the three-month real US Treasury bill rate, and the 10-year real US government bond rate as right-hand-side variables.

Row 3 presents these estimates. Accounting for fluctuations in the world business cycle reduces slightly the point estimates. The growth rate of Tobin's $q$ is now 15.4 percentage points above the pre-liberalization mean in year [0] as compared to 18.2 in Row 1 and 9.7 percentage points above the pre-liberalization mean in year $[+1]$ as compared to 13.2 in Row 1 . The point estimate in year [+2] is no longer statistically significant. The negative point estimate in year [+3] is stronger than without business cycle controls. Row 4 re-estimates the country-fixed effects model, but this time includes controls for fluctuations in the world business cycle. These results are almost identical to 
those in Row 3. Estimates using various leads and lags of all three business cycle controls were also tried but did not yield significantly different results. Regardless of the specification, the point estimates for the growth rate of $q$ in years [0] and $[+1]$ are positive and statistically significant.

\section{B. Investment}

The following panel regression evaluates the response of the growth rate of the average firm's capital stock to liberalization:

$\Delta(\ln K)_{i j t}=\alpha+L i b[0]+L i b[+1]+L i b[+2]+L i b[+3]+F I R M_{i}+\varepsilon_{i j t}$

This specification is identical to Equation (1) except that instead of Tobin's $q$, the lefthand-side variable is now the growth rate of the capital stock.

Table 3, Panel B presents the results. There is a strong relationship between liberalization and the growth rate of the capital stock. Row 1, which presents the firmfixed effects estimates, indicates a strong lagged response of the capital stock to liberalization. The growth rate of the capital stock is 5.5 percentage points above the preliberalization mean in year [+1], 6.9 percentage points above the mean in year [+2], and 3.9 percentage points above the mean in year [+3]. The estimates from the country-fixed effects specification in Row 2 are almost identical to the firm-fixed effects specification in Row 1. The estimates in Rows 3 and 4 contain proxies for the world business cycle. The only significant change relative to the estimates in Rows 1 and 2 is that the year [0] estimates are now statistically significant.

It is useful to think about the economic significance of the estimated effect of liberalization on investment. The average growth rate of the capital stock across all 369 
firms in the pre-liberalization period is 10 percent per year. Now make the following assumptions: the production function for all firms is Cobb-Douglas, there is no technological progress, the size of the labor force is constant, and capital's share in output is one-third. With this set of assumptions the pre-liberalization growth rate of output for the average firm equals one-third times 10 percent, or 3.3 percent per year.

The estimates in Row 4 of Table 3 show that the growth rate of the capital stock exceeds the pre-liberalization mean by 4.7 percentage points in year [0], 4.7 percentage points in year [+1], 8.2 percentage points in year [+2], and 6.9 percentage points in year [+3]. To get a rough sense of how much faster the average firm will grow as a result of liberalization multiply each of these coefficient estimates by a third, and add the resulting number to 3.3 percent. Doing so suggests that instead of growing at 3.3 percent per year, the average firm will grow by 4.9 percent in year [0], 4.9 percent in year [+1], 6 percent in year [+2], and 5.6 percent in year [+3]. Rough as they may be, these are large numbers with non-trivial welfare implications when one considers that the firms in this sample constitute roughly 40 percent of the total market capitalization of publicly traded firms in these countries.

\section{Cross-Sectional Evidence: Does Risk Sharing Drive the Reallocation of Capital?}

Allocative Efficiency also makes predictions about the cross-sectional behavior of investment following stock market liberalizations. Liberalization alters the set of systematic risks for the representative investor, because the relevant benchmark for pricing individual stocks switches from the local stock market index to a world index. Stock prices should rise in sectors where systematic risk - and therefore the cost of 
capital — falls. The stock price data are consistent with this prediction (Chari and Henry 2001). But optimal smoothing of production risk in an open-capital-market world also requires the reallocation of physical capital in accordance with changes in systematic risk. All else equal, we should observe relatively more investment by firms whose systematic risk falls and relatively less investment by those whose systematic risk rises.

To investigate these predictions, define the variable $D I F C O V$ as follows: The covariance of a firm's stock return with the local market index minus the covariance of that firm's stock return with the world stock market index. Allocative Efficiency predicts that the capital stocks of high $D I F C O V$ firms will grow more quickly than those of the low DIFCOV firms following liberalization. We move towards testing this prediction by constructing two measures of DIFCOV for each firm in the sample. For firm $i$ in country $j$, DIFCOV1 is calculated as follows. First we calculate the historical covariance of firm $i$ 's annual stock return with the annual aggregate market return for country $j$. Second, we calculate the covariance of firm $i$ 's annual stock return with the annual return on the Morgan Stanley World Capital Market Index (MSCI). DIFCOV1 equals the first covariance minus the second. We calculate DIFCOV2 by following the same steps, but instead of using stock returns to calculate covariances, we use growth rates of real earnings.

We test the prediction that capital will be reallocated towards sectors that provide the greatest diversification benefits following liberalization by regressing the cumulative deviation of the percentage change in the capital stock from its pre-liberalization mean over various horizons on DIFCOV1 and DIFCOV2, a proxy for the change in expected earnings growth, and country-fixed effects. 
$\hat{K} D E V_{i j t}=\alpha+\beta_{1} D I F C O V 1_{i}+\beta_{2} D I F C O V 2_{i}+\Delta$ Earnings + Country $_{j}+\varepsilon_{i j t}$

The symbol $\hat{K} D E V_{i j t}$ denotes the following. For country $j$, it is the growth rate of firm $i$ 's capital stock at time $t$ minus the average growth rate of firm $i$ 's capital stock in the preliberalization period. The country-fixed effects remove the liberalization shock that is common to all firms: a countrywide fall in the cost of capital.

The data do not support the prediction that capital is reallocated across firms in accordance with optimal risk sharing. The estimates in Rows 1 and 2 of Table 4 show that the cumulative change in the capital stock over the period $[0,+3]$ is not significantly related to either measure of diversification. The coefficients on DIFCOVI, the measure based on returns covariances, and DIFCOV2, the measure based on firm level earnings covariances, are insignificant in all specifications. Moving across columns, equation (3) was also estimated using cumulative capital stock growth over the following horizons: $[0$, $+2],[0,+1],[+1,+2]$. The point estimates on DIFCOV1 and DIFCOV2 are statistically insignificant in each of these specifications.

\section{A. Is the Reallocation of Capital Related to Changes in Tobin's $q$}

A fall in the cost of capital stemming from risk sharing is just one of the two channels through which liberalization may affect investment. Liberalization may also change firms' expected future profitability. Movements in Tobin's $q$ capture changes in both the cost of capital and expected future profitability. Therefore, as an additional test of Allocative Efficiency we examine whether post-liberalization changes in the capital stock are related to the liberalization-induced changes in Tobin's $q$. All else equal, firms 
that experience the largest increases in $q$ should also experience the largest increases in investment.

We examine this prediction as follows. For each firm, we regress the cumulative deviation of the growth rate of the capital stock from its pre-liberalization mean, over various horizons, on the on-impact deviation of the growth rate of $q$ from its preliberalization mean. Row 3 of Table 4 shows that the result is the same for all event windows. The on-impact deviation of the growth rate of Tobin's $q$ has no explanatory power for post liberalization changes in the capital stock. As a final test of the theory we replace the on-impact change in $q$ with the on-impact change in the stock price. The results, presented in Row 4, are the same. The cross-sectional changes in the price of capital have no explanatory power for the cross-sectional changes in quantities of capital.

\section{Discussion}

It is important to understand whether physical capital is efficiently reallocated when barriers to capital movements are removed. Previous work shows that liberalization induces stock price revaluations (Henry, 2000a). These revaluations have two components. The first is common to all firms: a fall in the risk-free rate as the country moves from financial autarky to financial integration with the rest of the world. The second is specific to any given firm. Prices rise for firms whose systematic risk falls and fall for firms whose systematic risk rises (Chari and Henry, 2001).

These revaluations signal to managers that they can increase shareholder welfare by investing in physical capital (Blanchard et al. 1993; Morck, Shleifer, and Vishny, 1990; Wurgler, 2000). On average, investment should increase for all firms in the 
economy because the risk free rate has fallen. This is the time series implication of liberalization for the reallocation of capital across countries. We should also observe relatively more investment by firms whose systematic risk falls and relatively less investment by those firms whose systematic risk rises. This is the cross-sectional implication of liberalization for the reallocation of capital within countries.

The time series results are more consistent with Allocative Efficiency than with Animal Spirits. The typical firm in our sample experiences a significant increase in both Tobin's $q$ and investment around liberalization. The cross-sectional results are more consistent with Animal Spirits than with Allocative Efficiency. The reallocation of physical investment following liberalization bears no significant correlation to changes in systematic risk or investment opportunities.

Taken together, these results suggest that neither view provides a complete description of the adjustment process. Liberalizing capital markets appears to facilitate an efficient transfer of capital from low to high-return countries. But capital is fungible, so there is no guarantee that the inflow of real resources will be allocated efficiently across firms. However, if the magnitude of the firm-specific component of the revaluation is small, then its impact on resource allocation may also be small. Therefore, an alternative interpretation of our results is that the firm-specific fall in the cost of capital pales in comparison to the fall in the average cost of capital for all publicly traded firms.

Yet another alternative interpretation is that the absence of empirical support for the cross-sectional predictions stems not from Animal Spirits, but a lack of empirical power. Data availability restricts the empirical analysis to only three years following the 
liberalizations, but the reallocation of capital across firms may take several years to complete. This explanation appears at odds with the adjustments to the aggregate capital stock that take place within the three-year window. Investment responds to liberalization, but it does so in a somewhat indiscriminate manner.

This paper provides a first step towards understanding whether physical investment is efficiently reallocated when barriers to capital movements are removed. Future work should try to determine the factors that drive the cross-sectional distribution of new capital across firms within a given country. There are models of investment in the corporate finance literature that generate predictions about the cross-sectional determinants of firm-level investment, which could be applied to capital account liberalization. For example, it could be the case that firms in industries that are more dependent on external finance show the largest increase in investment (Rajan and Zingales, 1998). Yet other explanations could be related to the political economy of liberalization. Firms that receive preferential government treatment may be better positioned to raise stock market financing than other firms (Johnson and Mitton, 2001). Preferential treatment may in turn determine which firms are made investible. The available data cannot resolve these issues. Nevertheless, they do bring us a step closer to understanding whether removing barriers to international capital flows promotes efficient resource allocation. Future research may bring us yet nearer. 


\section{References}

Bekaert and Harvey (2000). "Foreign Speculators and Emerging Equity Markets" Journal of Finance, 55, 565-613.

Bhagwati, Jagdish (1998). "The Capital Myth” Foreign Affairs, May/June pp. 7-12.

Blanchard, Olivier J., Rhee, C., and Lawrence Summers (1993). "The Stock Market, Profit, and Investment" Quarterly Journal of Economics, Vol. 108, pp. 115-36

Booth, Laurence, Varouj Aivazian, Asli Demirguc-Kunt, and Vojislav Maksimovic (2001). Capital Structures in Developing Countries, The Journal of Finance, Vol. 56 , pp. $87-130$

Chari, Anusha and Peter Blair Henry (2001). Stock Market Liberalizations and the Repricing of Systematic Risk, NBER Working Paper No. 8265

Fischer, Stanley (1998). Capital Account Liberalization and the Role of the IMF Princeton Essays in International Finance 207, 1-10.

Henry, Peter Blair. (2000a). "Stock Market Liberalization, Economic Reform, and Emerging Market Equity Prices," Journal of Finance, Vol. 55, No. 2, pp. 529-64.

Henry, Peter Blair. (2000b). "Do Stock Market Liberalizations Cause Investment Booms?" Journal of Financial Economics, Vol. 58, Nos. 1-2, pp. 301-334.

International Finance Corporation. (1999). The IFC Indexes: Methodology, Definitions, and Practices. Washington, D.C.

Johnson, Simon and Todd Mitton (2001). Cronyism and Capital Controls: Evidence From Malaysia, MIT Working Paper.

Morck, Randall, Andrei Shleifer, and Robert Vishny (1990). "The Stock Market and Investment: Is the Market a Sideshow?" Brookings Papers on Economic Activity, pp. 157-215.

Morck, Randall, Bernard Yeung, and Wayne Yu. (2000). "The Information Content of Stock Markets: Why Do Emerging Markets Have Synchronous Stock Price Movements?" Journal of Financial Economics, Vol. 58, pp. 215-260

Obstfeld, Maurice (1994). "Risk-Taking, Global Diversification and Growth," American Economic Review, Vol. 84, No. 5, pp. 1310-1329.

Rajan, Raghuram and Luigi Zingales (1998) Financial Development and Growth American Economic Review 
Rodrik, Dani (1998). Who needs capital account convertibility? Princeton Essays in International Finance 207, 55-65.

Singh, Ajit, Javed Hamid, Bahram Salimi, and Y. Nakano (1992). Corporate Financial Structures in Developing Countries, Technical paper \#1, International Finance Corporation, Washington, D.C.

Stiglitz, Joseph (2000a). "What I Learned at the World Economic Crisis" The New Republic, April 17, pp. 56-60.

Stiglitz, Joseph (2000b). "Sound the Alarm: Economist Rips Washington's Market Bolsheviks" Barron's, April 17, pp. 32-34.

Stiglitz, Joseph (2000c) "Capital Market Liberalization, Economic Growth, and Instability" World Development, June, Vol. 28, No.6, pp. 1075-1086

Stulz, René M. (1999). "International Portfolio Flows and Security Markets" in Martin Feldstein, ed. International Capital Flows. Chicago: University of Chicago Press.

Von Furstenberg, G. (1977). "Corporate Investment: Does Market Valuation Matter in The Aggregate?" Brookings Papers on Economic Activity, 2, pp. 347-407.

Wurgler, Jeffrey (2000). "Financial Markets and the Allocation of Capital," Journal of Financial Economics, Vol. 58, pp. 187-214 


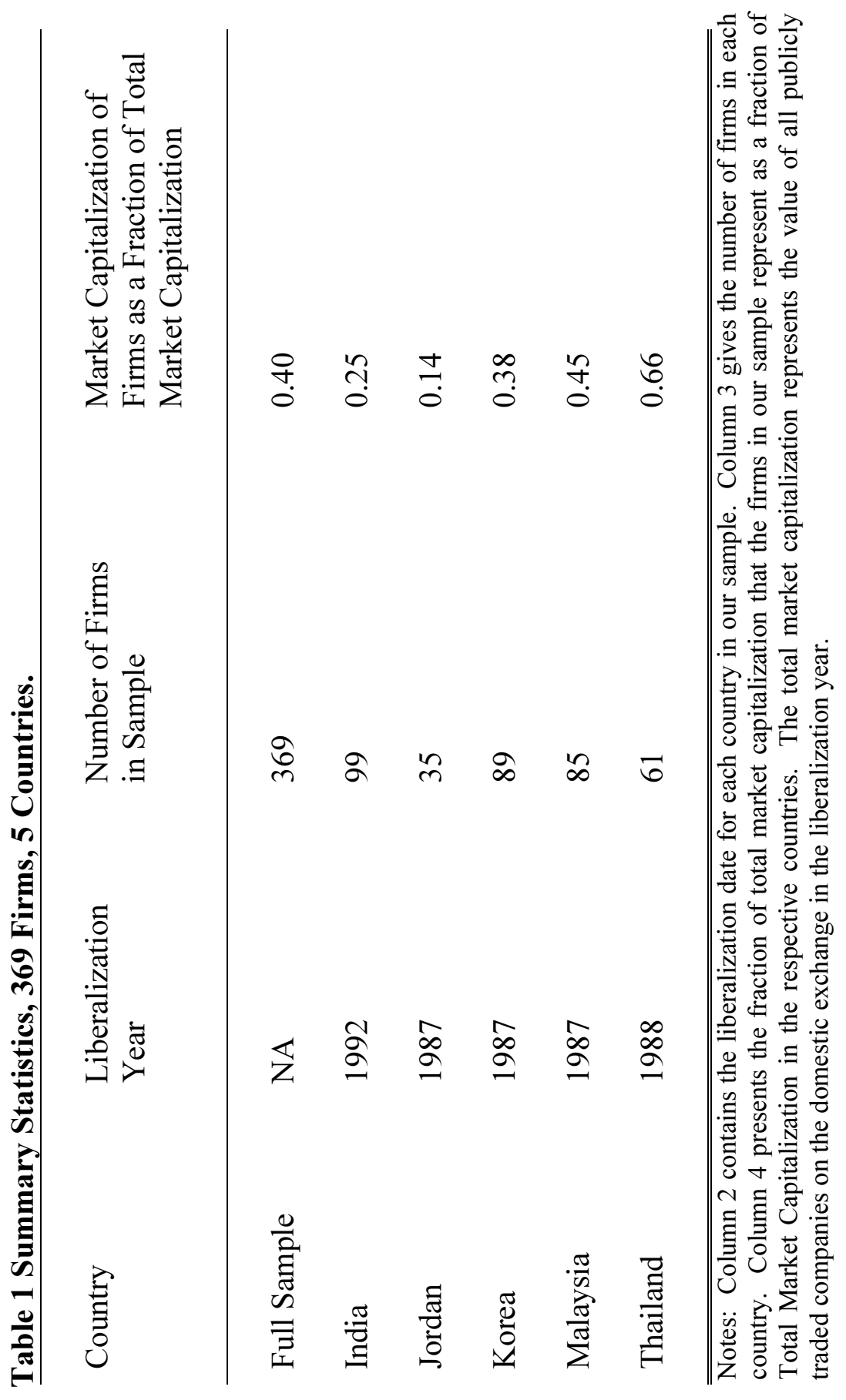




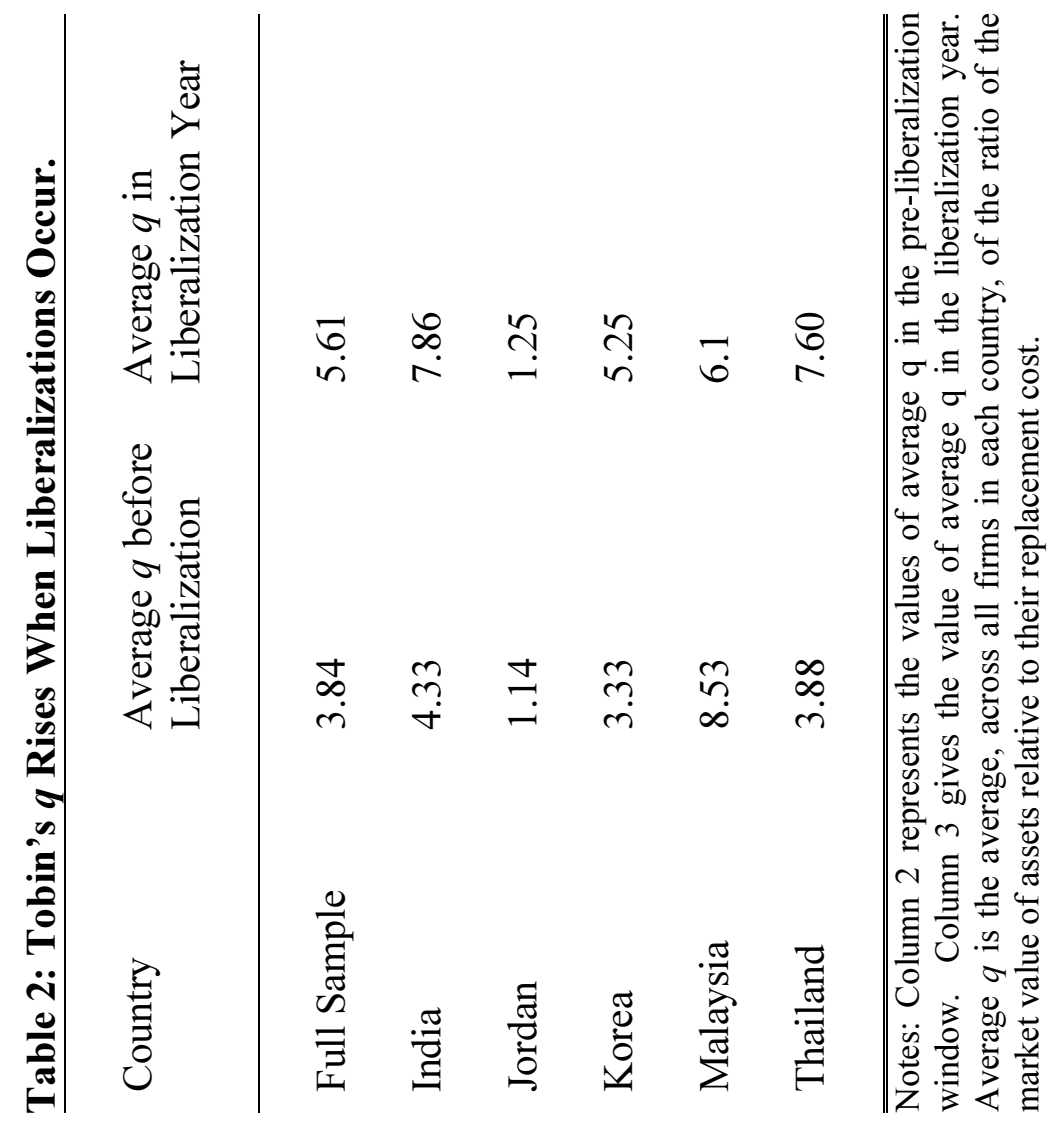




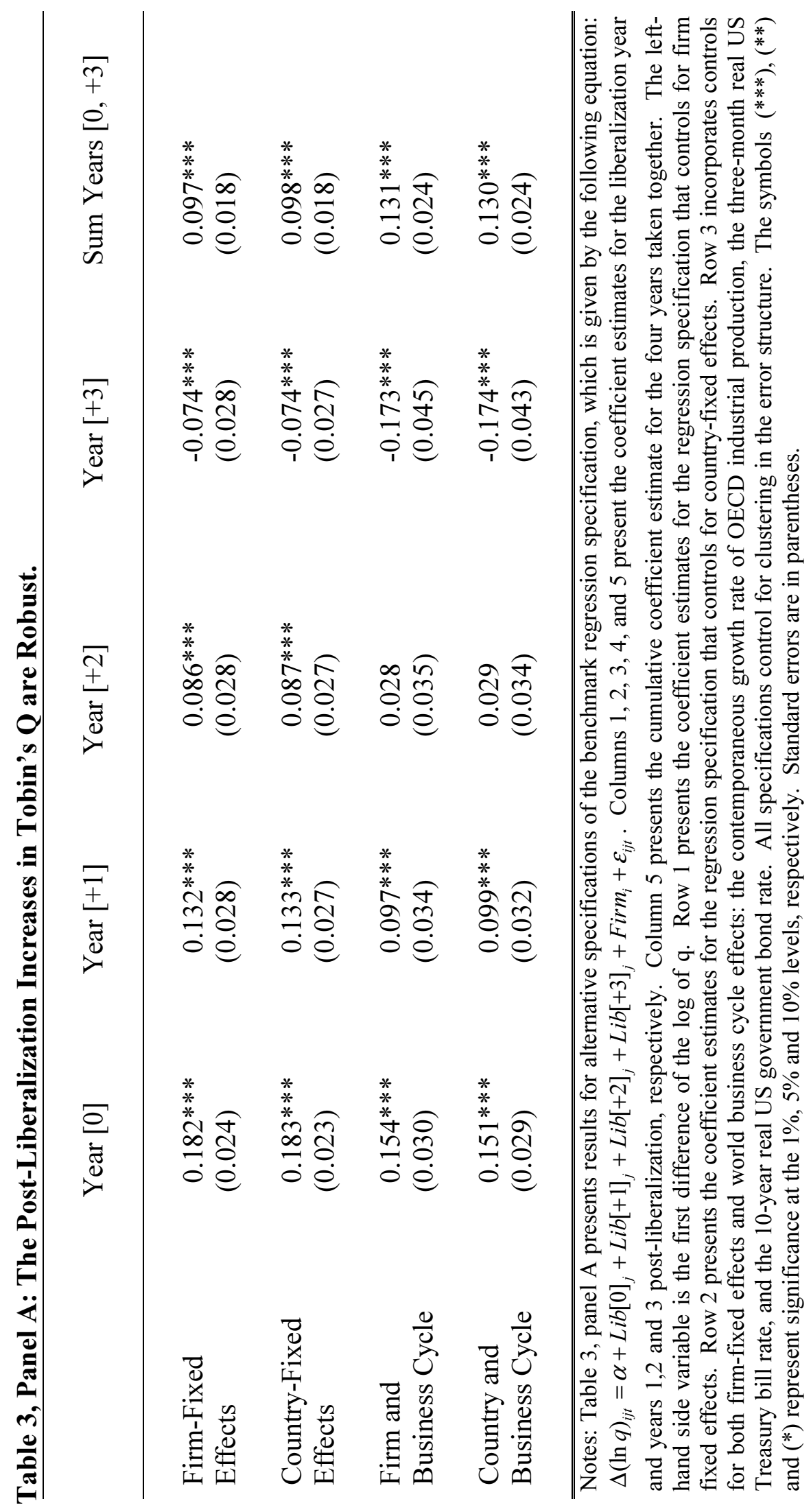

๙ 


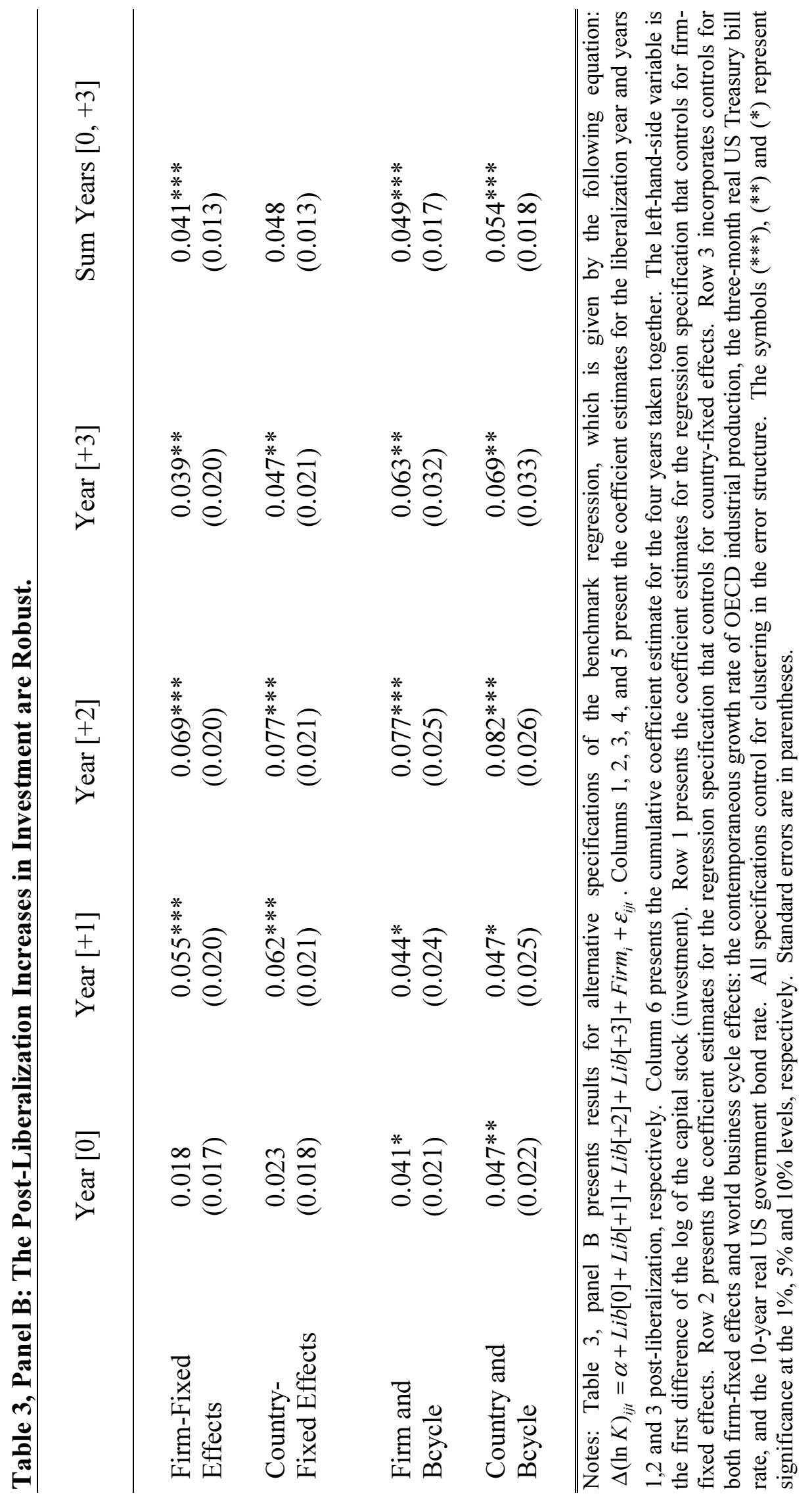




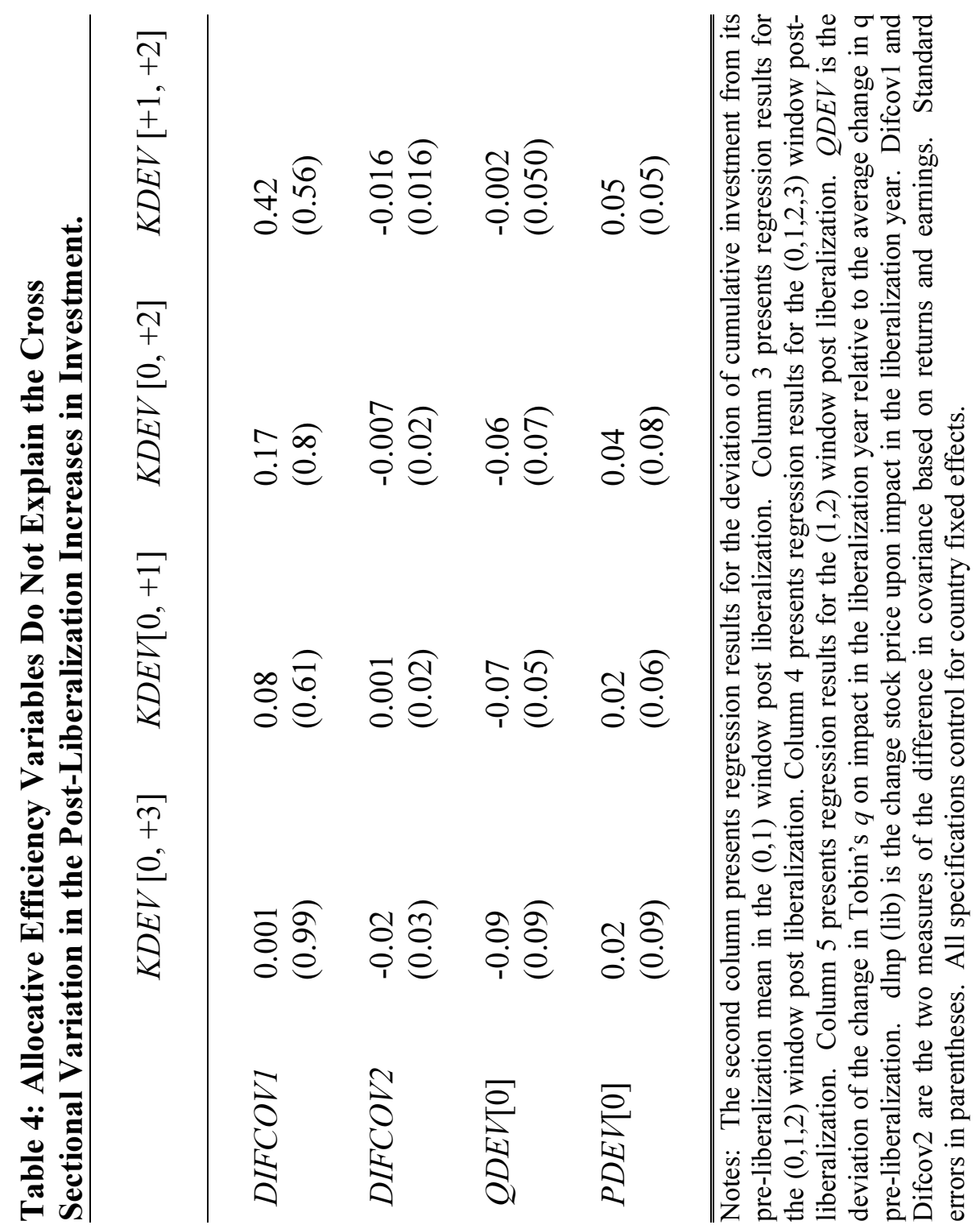




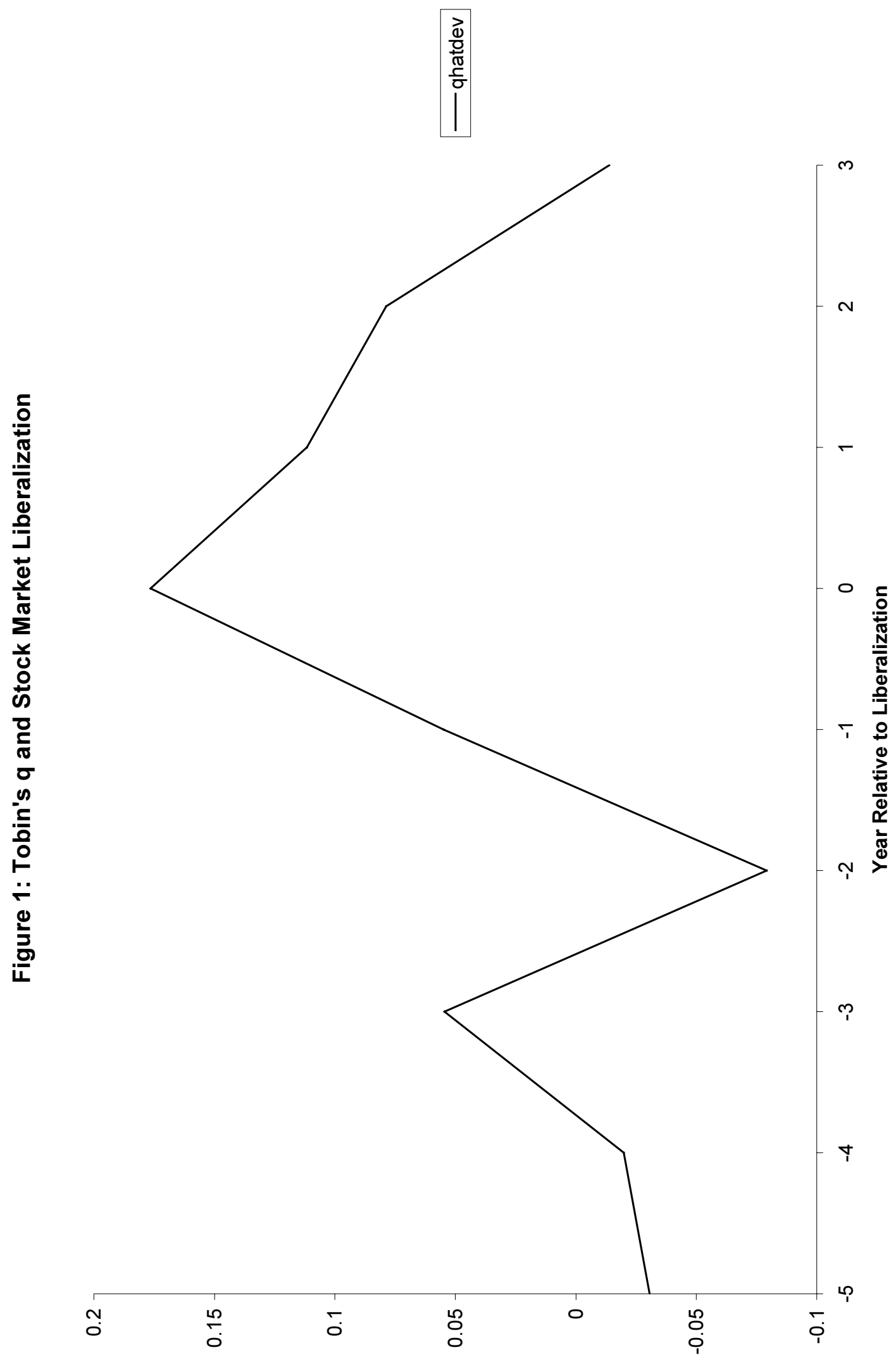




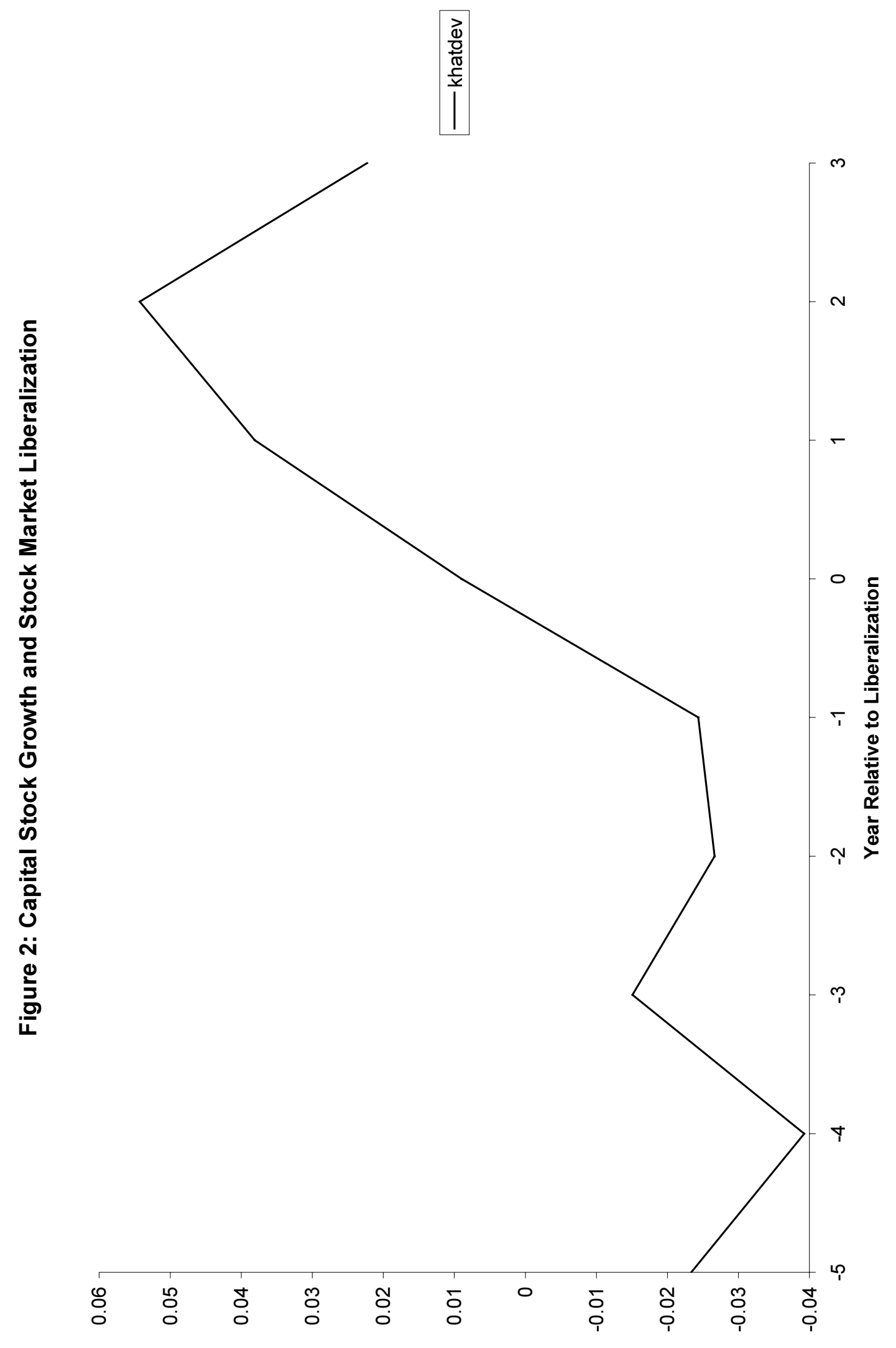

